Article

\title{
Cyanogenesis in Macadamia and Direct Analysis of Hydrogen Cyanide in Macadamia Flowers, Leaves, Husks, and Nuts Using Selected Ion Flow Tube-Mass Spectrometry
}

\author{
Hardy Z. Castada ${ }^{1, * \mathbb{C}}$, Jinyi Liu ${ }^{2}$, Sheryl Ann Barringer ${ }^{1}$ and Xuesong Huang ${ }^{2, *}$ \\ 1 Department of Food Science and Technology, The Ohio State University, 2015 Fyffe Road, Columbus, \\ OH 43210, USA; barringer.11@osu.edu \\ 2 Department of Food Science and Engineering, Jinan University, Guangzhou 510632, China; \\ ljy@stu2016.jnu.edu.cn \\ * $\quad$ Correspondence: castada.1@osu.edu (H.Z.C.); thxs@jnu.edu.cn (X.H.); Tel.: +1-614-247-1945 (H.Z.C.)
}

Received: 16 January 2020; Accepted: 7 February 2020; Published: 11 February 2020

\begin{abstract}
Macadamia has increasing commercial importance in the food, cosmetics, and pharmaceutical industries. However, the toxic compound hydrogen cyanide (HCN) released from the hydrolysis of cyanogenic compounds in Macadamia causes a safety risk. In this study, optimum conditions for the maximum release of HCN from Macadamia were evaluated. Direct headspace analysis of HCN above Macadamia plant parts (flower, leaves, nuts, and husks) was carried out using selected ion flow tube-mass spectrometry (SIFT-MS). The cyanogenic glycoside dhurrin and total cyanide in the extracts were analyzed using HPLC-MS and UV-vis spectrophotometer, respectively. HCN released in the headspace was at a maximum when Macadamia samples were treated with $\mathrm{pH} 7$ buffer solution and heated at $50{ }^{\circ} \mathrm{C}$ for $60 \mathrm{~min}$. Correspondingly, treatment of Macadamia samples under these conditions resulted in $93-100 \%$ removal of dhurrin and $81-91 \%$ removal of total cyanide in the sample extracts. Hydrolysis of cyanogenic glucosides followed a first-order reaction with respect to HCN production where cyanogenesis is principally induced by $\mathrm{pH}$ changes initiating enzymatic hydrolysis rather than thermally induced reactions. The effective processing of different Macadamia plant parts is important and beneficial for the safe production and utilization of Macadamia-based products.
\end{abstract}

Keywords: Macadamia; hydrogen cyanide; cyanogenic glycosides; headspace analysis; SIFT-MS

\section{Introduction}

Macadamia-based commercial products have rapidly increased in recent years. In addition to Macadamia nuts, Macadamia flowers, husks, leaves, and shells are now widely used as a source of functional foods, beverages, and raw materials in cosmetics, feed, and other applications. Abundant antioxidant substances, such as polyphenols, can be extracted from Macadamia skin and husks for utilization in the food and pharmaceutical industries [1-3]. Bioactive constituents in Macadamia are believed to provide health benefits such as improved blood lipid profiles, decreased inflammation, oxidative stress, and reduced cardiovascular disease risk factors $[4,5]$.

Species within the genus Macadamia, however, contain cyanogenic glycoside compounds, which are secondary metabolites that release hydrogen cyanide through cyanogenesis [6,7]. Cyanogenic glycosides are widely distributed in plants and are usually $O-\beta$-glycosidic derivatives of $\alpha$-hydroxynitriles originating from the five hydrophobic protein amino acids tyrosine, phenylalanine, valine, leucine, and isoleucine [8,9]. Biological cyanogenesis requires unstable cyanohydrin or a stable cyanogen and degradative enzymes $[10,11]$. In plants, cyanogenesis mostly occurs via 
hydrolysis of cyanogenic glycosides that is enzymatically catalyzed by one or more glycosidases and $\alpha$-hydroxynitrile lyases. These substrates and enzymes are localized in separate vacuoles intact within the subcellular or tissue level of the plant so that under normal physiological conditions, hydrolysis does not occur and autotoxicity is prevented [12,13]. However, tissue disruption allows mixing of substrate and enzymes initiating cyanogenesis and subsequently, hydrolysis [6,7]. Figure 1 shows a two-step enzymatic hydrolysis of dhurrin (4-hydroxymandelonitrile- $\beta$-D-glucoside), a cyanogenic glycoside found in Macadamia. A more complex biosynthetic pathway for dhurrin hydrolysis is available in the literature [14,15]. In Figure 1, hydrolysis is initially catalyzed by endogenous dhurrinase (a $\beta$-D-glucoside glucohydrolase) producing D-glucose and an unstable intermediate, p-hydroxy-(S)-mandelonitrile. The nitrile group is rapidly cleaved off of this intermediate, producing hydrogen cyanide and $p$-hydroxybenzaldehyde, which is catalyzed enzymatically by $\alpha$-hydroxynitrile lyase $[16,17]$.

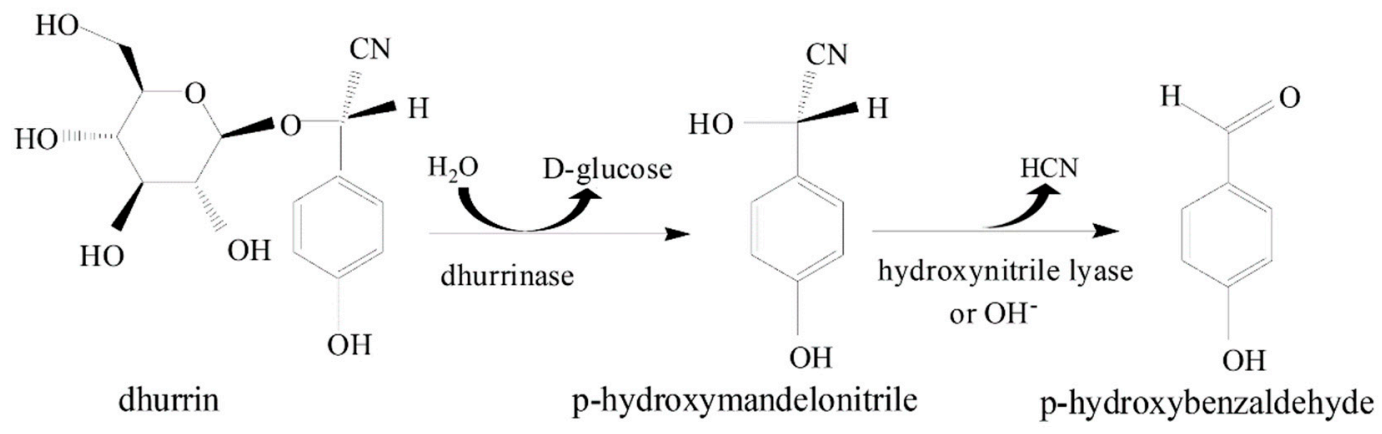

Figure 1. Enzymatic hydrolysis of dhurrin $[17,18]$.

Acute and chronic toxicities of hydrogen cyanide from plant-derived food have been reported $[16,19,20]$. Ingestion of $0.5-3.5 \mathrm{mg}$ cyanide/ $\mathrm{kg}$ body weight results in acute toxicity. Sublethal doses could lead to headache, hyperventilation, vomiting, weakness, abdominal cramps, and partial circulatory and respiratory systems failure. Moreover, cyanide can inhibit cellular respiration, which could result in fatal poisoning $[7,16,21]$. The concentration of cyanogenic glycosides, such as dhurrin and proteacin, varies among plant species of Macadamia (i.e., M. ternifolia, M. integrifolia, and M. tetraphylla) [6,22]. These compounds are also unevenly distributed within the different parts of a plant (i.e., nuts, seeds, and roots), and their concentrations change at different developmental stages from seed germination to plant maturation $[23,24]$.

In this study, different conditions causing the hydrolysis of cyanogenic compounds in Macadamia that subsequently produce hydrogen cyanide gas were evaluated. Most characterization studies in Macadamia and other plants only involved analysis of cyanogenic glycosides using time-consuming assays coupled with HPLC analysis $[6,25,26]$. Furthermore, typical analysis of releasable cyanide uses tedious assays and subsequent spectrophotometry or LC- or GC-MS analysis $[14,27,28]$. In this study, hydrogen cyanide was measured directly above the headspace of the different parts of the Macadamia plant including the flowers, leaves, husks, and nuts using selected ion flow tube-mass spectrometry (SIFT-MS). To our knowledge, this is the first study to measure hydrogen cyanide in real time and directly above the headspace of Macadamia samples using SIFT-MS. The rapid and real-time analysis of hydrogen cyanide is particularly important in the processing of the various parts of Macadamia that are known to contain cyanogenic glycosides and can subsequently hydrolyze and undergo cyanogenesis. The optimum conditions (heating temperature, heating time, and $\mathrm{pH}$ ) for the hydrolysis of cyanogenic glycosides via cyanogenesis toward the maximum generation of hydrogen cyanide were determined. Identifying these conditions would be useful in the pre-processing of Macadamia to ensure maximum hydrolysis of cyanogenic glucoside, leading to maximum release and volatilization of hydrogen cyanide and ultimately toward the safe production and utilization of Macadamia-based products especially as ingredients in food and beverages. 


\section{Materials and Methods}

\subsection{Sample Preparation}

Macadamia (M. integrifolia) flowers, leaves, nuts, and three variety of husks (A16, Oc, and 695) were donated by Shouxiang Township Organic Agricultural Products Development Co., Ltd. (Guangxi, China). The three varieties of $M$. integrifolia husks were introduced and propagated in China from Australia and are hybrid cultivars selected from different plantations or open-pollinated progeny (variety A16). HPLC-grade water, hexane, $\mathrm{Na}_{2} \mathrm{HPO}_{4}$, and citric acid were purchased from Fisher Scientific (Fisher Chemical, Fair Lawn, NJ, USA).

Macadamia flowers and leaves were freeze-dried, ground, and sifted. Macadamia husks were air-dried, crushed, and sifted. Macadamia nuts were crushed, defatted using hexane, and air-dried. All samples were stored in sealed bottles under freezing temperature $\left(-20^{\circ} \mathrm{C}\right)$.

\subsection{Buffer Preparation}

$\mathrm{Na}_{2} \mathrm{HPO}_{4}$ solution $(0.2 \mathrm{~mol} / \mathrm{L})$ was prepared by dissolving $14.2 \mathrm{~g} \mathrm{Na} \mathrm{HPO}_{4}$ with $500 \mathrm{~mL}$ carbon dioxide-free HPLC water. Citric acid solution $(0.1 \mathrm{~mol} / \mathrm{L})$ was prepared by dissolving $10.51 \mathrm{~g}$ citric acid with $500 \mathrm{~mL}$ HPLC water.

Different volumes of $0.2 \mathrm{~mol} / \mathrm{L} \mathrm{Na}_{2} \mathrm{HPO}_{4}$ solution and $0.1 \mathrm{~mol} / \mathrm{L}$ citric acid were mixed to prepare various buffer solutions with $\mathrm{pH} 2,3,4,5,6,7,8$, and 9. The $\mathrm{pH}$ of each solution or sample mixture was measured using a Model 10 pH meter (Denver Instrument Company, Arvada, CO, USA).

\subsection{Optimization of Heating Temperature and Heating Time}

Macadamia samples (0.100 g) were subjected to different heating times and temperatures to evaluate the optimum conditions for the maximum hydrolysis of cyanogenic compounds and maximum production of hydrogen cyanide. Samples were heated at 30, 40, 50, 60, 70, or $100{ }^{\circ} \mathrm{C}$. At each temperature, samples were heated for $20,30,45,60,80,100$, or $120 \mathrm{~min}$. Immediately after heating, the headspace concentration of hydrogen cyanide was measured using SIFT-MS.

\subsection{Optimization of $p H$-Buffering Solution}

To evaluate the optimum $\mathrm{pH}$ for maximum enzymatic activity and the hydrolysis reaction, $0.100 \mathrm{~g}$ powdered Macadamia flower sample was dissolved in $0.75 \mathrm{~mL} \mathrm{Na}_{2} \mathrm{HPO}_{4}$-citric acid buffered solutions with different $\mathrm{pH}(2,3,4,5,6,7,8$, or 9$)$. The solutions were heated at $50{ }^{\circ} \mathrm{C}$ for $15,30,60,90$, and $120 \mathrm{~min}$. The headspace concentration of hydrogen cyanide was immediately measured using SIFT-MS.

\subsection{Headspace Cyanide Analysis Using SIFT-MS}

Headspace hydrogen cyanide (HCN) was analyzed using a V200 selected ion flow tube-mass spectrometry, SIFT-MS (Syft ${ }^{\mathrm{TM}}$ Technologies, Middleton, Christchurch, New Zealand). Using selected ion scan mode, $\mathrm{HCN}$ was measured using the $\mathrm{H}_{3} \mathrm{O}^{+}$precursor ion to detect a protonated $\mathrm{HCNH}^{+}$at $m / z 28$ with a reaction rate, $k$, of $3.8 \times 10^{-9} \mathrm{~cm}^{3} \mathrm{~s}^{-1}$. SIFT-MS has recently been used for the headspace analysis of various compounds in different food (oil, cheese, and garlic) and breath matrices [29-34]. For the headspace detection of HCN using SIFT-MS, $0.100 \mathrm{~g}$ of Macadamia flowers, leaves, husks, or defatted nuts sample was weighed into individual $500 \mathrm{~mL}$ Schott bottles. Then, $0.75 \mathrm{~mL}$ HPLC water or $\mathrm{Na}_{2} \mathrm{HPO}_{4}$-citric acid buffer was added, and the solution was mixed and heated $\left(50{ }^{\circ} \mathrm{C}\right)$ in a water bath (Precision Inc., Winchester, VA, USA).

A stock cyanide standard solution $(1002 \pm 5 \mathrm{mg} / \mathrm{L} \mathrm{KCN}$ in $0.1 \% \mathrm{NaOH}$, Specpure, Alfa Aesar, Tewksbury, MA, USA) was used to prepare the working standard aqueous solutions $(0,20,40,80$, $160,200,425$, and $1000 \mu \mathrm{g} / \mathrm{L}$ ). After this, $1 \mathrm{~mL}$ of the working standard solution or matrix blank (HPLC water) was transferred to a $100 \mathrm{~mL}$ Schott bottle sealed with a septum-lined screw cap. The working standards were heated at $50{ }^{\circ} \mathrm{C}$ for $30 \mathrm{~min}$ to allow for headspace equilibrium prior to SIFT-MS 
analysis. Figure $2 \mathrm{~A}$ shows the concentration of cyanide in the headspace $\left(p p b_{v}\right)$ as a function of cyanide concentration in aqueous solution $(\mu \mathrm{g} / \mathrm{L})$ generated by a linear regression model. The correlation coefficient $\left(R^{2}\right)$ for the calibration curve was 0.9993 which signifies that the linear regression model fits the data having $<0.0001$ significance probability associated with the F statistic ( $\operatorname{Pr}>\mathrm{F}$ ) at $95 \%$ confidence intervals.
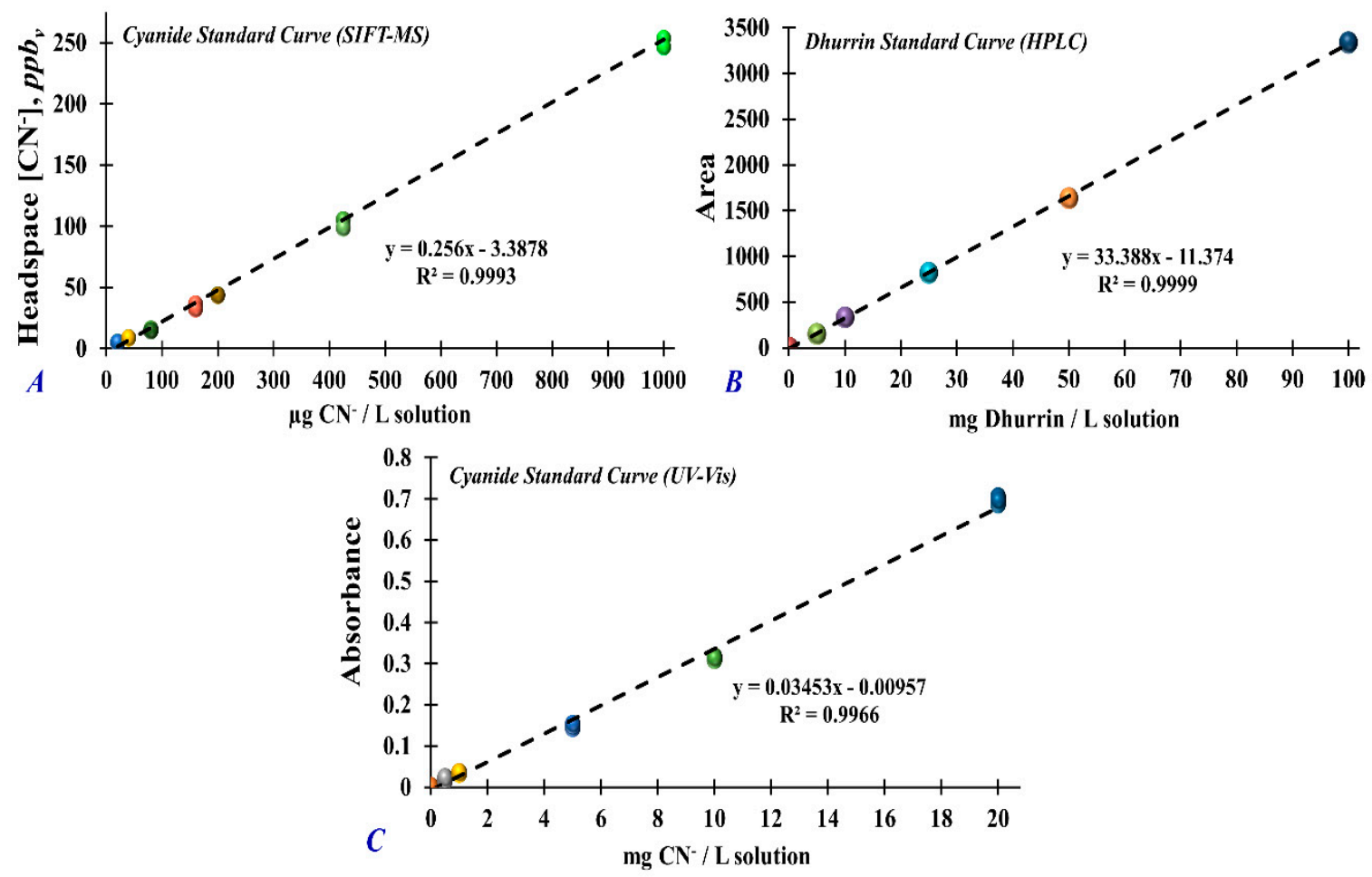

Figure 2. Standard calibration curve and linear regression analysis of (A) headspace cyanide concentration $\left(p p b_{v}\right)$ measured by selected ion flow tube-mass spectrometry (SIFT-MS) as a function of cyanide concentration in aqueous solution $(\mu \mathrm{g} / \mathrm{L})$; (B) peak area of dhurrin measured by HPLC-DAD (diode array detector) as a function of dhurrin concentration in aqueous solution ( $\mathrm{mg} / \mathrm{L}$ ); (C) UV-vis spectral absorbance of cyanide standards as a function of cyanide aqueous solution concentration $(\mathrm{mg} / \mathrm{L})$. Linear regression analyses were performed at 95\% confidence intervals.

Immediately after achieving headspace equilibrium by heating, headspace sampling was carried out by inserting a passivated sampling needle $(\sim 3.5 \mathrm{~cm})$ through the bottle's septum. The sample inlet flow rate was optimized to $0.35 \pm 0.01 \mathrm{Torr} \cdot \mathrm{L} \mathrm{s}^{-1}\left(26 \pm 1 \mathrm{~cm}^{3} \mathrm{~min}^{-1}\right.$ under standard ambient temperature $(298 \mathrm{~K})$. The scan duration was $120 \mathrm{~s}$. HPLC water or $\mathrm{Na}_{2} \mathrm{HPO}_{4}$-citric acid buffer was used as a blank solution. Lab air was analyzed in between samples to minimize carry-over effects and potential cross-contamination. Five replicates were performed in all analyses.

\subsection{Dhurrin Analysis in Plant Extracts Using HPLC}

Dhurrin extraction and analysis were performed based on the procedure by De Nicola and co-workers [35]. Briefly, $0.2 \mathrm{~g}$ of freeze-dried, powdered plant sample was weighed into a $25 \mathrm{~mL}$ centrifuge tube and $0.1 \mathrm{~g}$ of activated carbon (Fisher Chemical, Fair Lawn, NJ, USA) and $10 \mathrm{~mL}$ methanol (Fisher Chemical, Fair Lawn, NJ, USA) were added. The mixture was sonicated for $25 \mathrm{~min}$ at room temperature in a $435 \mathrm{~W}$ ultrasonic water bath (Model FS28H, Fisher Scientific, Fair Lawn, NJ, USA) and was left overnight in the tube. After 12-14 h, the mixture was centrifuged (Model Sorvall Legend XFR Centrifuge, Thermo Fisher Scientific, Waltham, MA, USA) for $30 \mathrm{~min}$ at $17,000 \times g$ and $10^{\circ} \mathrm{C}$ and was filtered through a Whatman no. 4 filter paper (GE Healthcare, Buckinghamshire, UK). The supernatant was collected and 1:1 (v/v) HPLC-grade water was added to the resulting solution. Prior 
to HPLC analysis, the diluted supernatant solution was filtered through a $0.2 \mu \mathrm{m}$ RC membrane filter (Phenomenex, Torrance, CA, USA) using a luer-type syringe (Henke-SASS Wolf GmbH, Tuttlingen, Germany) and was transferred into $1.5 \mathrm{~mL}$ amber vials for HPLC analysis.

Dhurrin stock standard solution was prepared by dissolving $1 \mathrm{mg}$ of pure dhurrin standard (Sigma Aldrich, St. Louis, MO, USA) with $1 \mathrm{~mL}$ of HPLC-grade water. Working standard solutions $(0,5,10$, 25,50 , and $100 \mathrm{mg}$ dhurrin/L solution) were prepared using aliquots of the stock standard solution and diluted with 1:1 $\mathrm{H}_{2} \mathrm{O} /$ methanol $(v / v)$ solution. Dhurrin standard solutions were transferred to $1.5 \mathrm{~mL}$ amber vials, correspondingly, for HPLC analysis. A solution of $1: 1 \mathrm{H}_{2} \mathrm{O} /$ methanol $(v / v)$ was used as matrix blank. Figure 2B shows the peak area of dhurrin as a function of dhurrin concentration in aqueous solution $(\mathrm{mg} / \mathrm{L})$ generated by the linear regression model. The correlation coefficient $\left(\mathrm{R}^{2}\right)$ for the calibration curve was 0.9999 which signifies that the linear regression model fits the data having a 0.0037 significance probability associated with the $\mathrm{F}$ statistic $(\mathrm{Pr}>\mathrm{F})$ at $95 \%$ confidence intervals.

Analysis of dhurrin from the sample extracts and standards were carried out using an HPLC (1100 Series, Agilent Technologies, Santa Clara, CA, USA) equipped with a G1311A quaternary pump, a G1322A degasser, a G1313 ALS autosampler, and a G1316A thermostated column compartment with a C-18 column. The chromatographic conditions involved a flow rate of $1 \mathrm{~mL} / \mathrm{min}$ by eluting with a gradient of water (A) and acetonitrile (B). The gradient program was set as follows: isocratic $10 \%$ for $1 \mathrm{~min}$, linear gradient to $30 \% \mathrm{~B}$ for $7 \mathrm{~min}$, and linear gradient to $10 \% \mathrm{~B}$ for $2 \mathrm{~min}$. Dhurrin was detected using a G1315B diode array detector (DAD) detector (Agilent Technologies, Santa Clara, CA, USA), and its absorbance was monitored at $232 \mathrm{~nm}$. Dhurrin's spectral peak was identified by comparing the retention time to that of pure dhurrin from the standard solutions. The resulting chromatograms (Figure 3) were automatically integrated using ChemStation software (Agilent Technologies Inc., Santa Clara, CA, USA). Five replicates per standard or sample extracts were performed in all analyses.

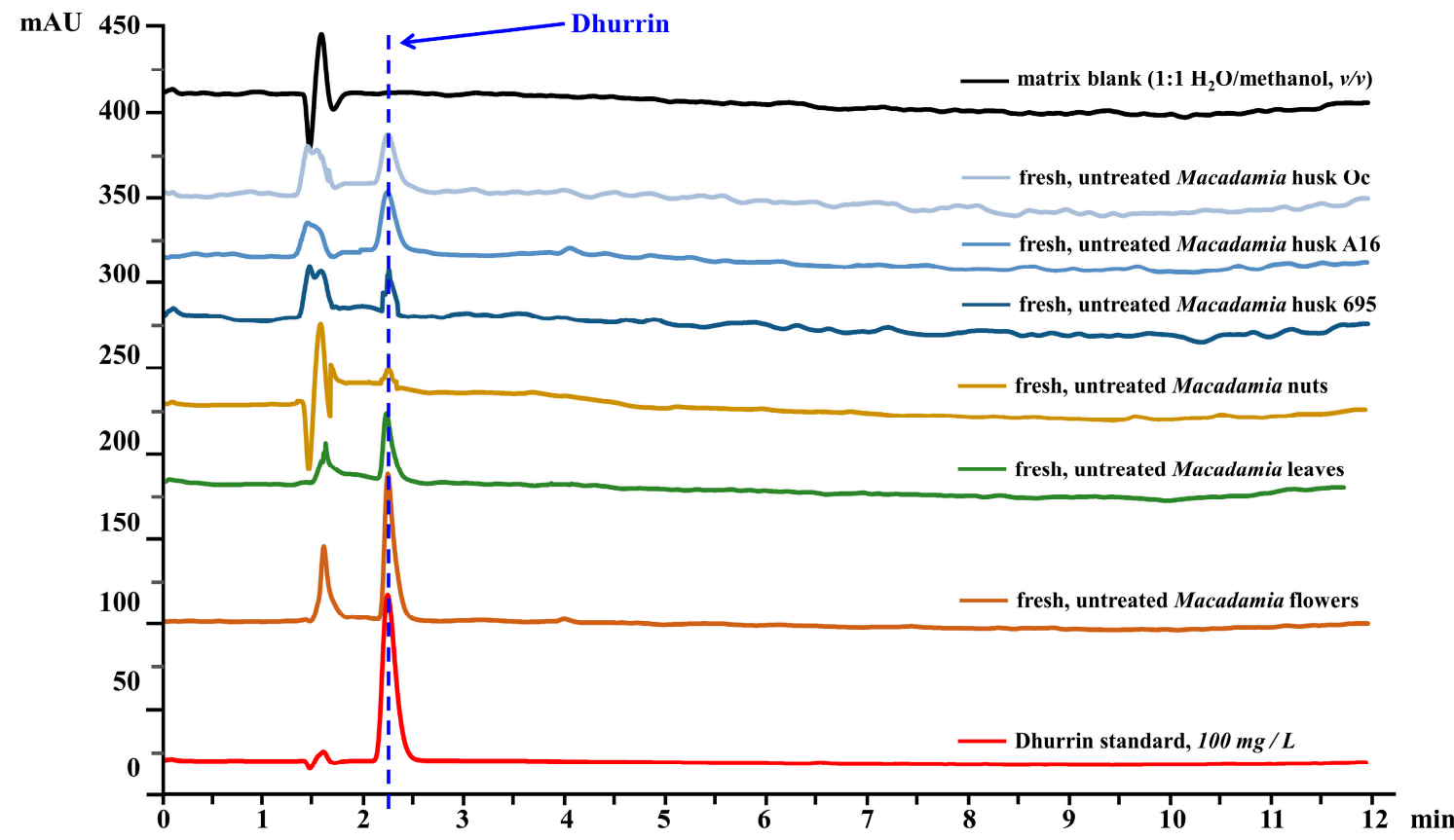

Figure 3. Representative HPLC chromatograms showing the dhurrin spectral peak in $100 \mathrm{mg} / \mathrm{L}$ dhurrin standard, matrix blank $\left(1: 1 \mathrm{H}_{2} \mathrm{O} /\right.$ methanol, $\left.v / v\right)$, and extracts of fresh, untreated Macadamia flowers, leaves, nuts, husk 695, husk A16, and husk Oc. Dhurrin was monitored at $232 \mathrm{~nm}$ absorbance using a diode array detector. 


\subsection{Total Cyanide Analysis in Plant Extracts Using UV-Vis Spectrophotometer}

The alkaline picrate method was used for the extraction and analysis of total cyanide as outlined by Sarkiyayi and Agar [36] and Omar and co-workers [37]. Five grams (5 g) dried samples and $50 \mathrm{~mL}$ HPLC water were placed in a conical flask which was soaked overnight and then filtered using Whatman no. 4 filter paper. One $\mathrm{mL}$ of the filtrate was transferred to a test tube, and $4 \mathrm{~mL}$ alkaline picric acid solution was added. The mixture was incubated for $5 \mathrm{~min}$ in a $95{ }^{\circ} \mathrm{C}_{2} \mathrm{O}$ bath. After color development, the absorbance of the mixture was measured at $490 \mathrm{~nm}$ using a Varian UV-vis spectrophotometer (Agilent, Cary 50 Bio UV/Visible, Santa Clara, CA, USA). Alkaline picric acid solution was prepared by mixing $1 \mathrm{~g}$ picric acid (2,4,6-trinitrophenol crystal, Electron Microscopy Sciences, Hatfield, PA, USA), $5 \mathrm{~g} \mathrm{Na}_{2} \mathrm{CO}_{3}$ (Fisher Scientific, Fair Lawn, NJ, USA), and $200 \mathrm{~mL}$ HPLC water.

A stock cyanide standard solution $(1002 \pm 5 \mathrm{mg} / \mathrm{L} \mathrm{KCN}$ in $0.1 \% \mathrm{NaOH})$ was used to prepare the working standard aqueous solutions $(0-20 \mathrm{mg} / \mathrm{L})$. One milliliter of the working standard solution or matrix blank (HPLC water) was transferred to a test tube. Four milliliters of alkaline picric acid solution was added, and the mixture was incubated for $5 \mathrm{~min}$ in a $95^{\circ} \mathrm{C}_{2} \mathrm{O}$ bath for color development. The solution absorbance was measured at $490 \mathrm{~nm}$ using a UV-vis spectrophotometer. Figure 2C shows the spectral absorbance as a function of the cyanide concentration in aqueous solution $(\mathrm{mg} / \mathrm{L})$ generated by the linear regression model. The correlation coefficient $\left(R^{2}\right)$ for the calibration curve was 0.9966 which signifies that the linear regression model fits the data having $<0.0001$ significance probability associated with the F statistic ( $\mathrm{Pr}>\mathrm{F}$ ) at 95\% confidence intervals. For analysis, 20 replicates per standard and 10 replicates per sample extract were used for UV-vis measurement.

\subsection{Statistical Analysis}

Data fitting, analysis of least square means, and regression analysis of the headspace hydrogen cyanide concentrations were carried out using the PROC REG and PROC MIXED options of Statistical Analysis System (SAS ${ }^{\circledR}$ Institute Inc., Cary, NC, USA). Analysis of variance (ANOVA) was performed to analyze the statistical differences of cyanide concentration between different samples using least significant difference of the means (LSD) technique using SAS. Significance was defined using $p<0.05$ ( $95 \%$ confidence intervals) for least square means comparison. Five replicates were performed in all analyses, except where otherwise specified. Limit of blank (LOB) and limit and detection (LOD) were determined using the methods described by Browne and Whitcomb [38] and Shrivastava and Gupta [39]. The estimated headspace $\mathrm{LOB}_{(P H B A)}$ and $\mathrm{LOD}_{(P H B A)}$ for $\mathrm{HCN}$ using SIFT-MS were 2.462 $p p b_{v}$ and $2.775 p p b_{v}$, respectively, which were determined using repeated headspace measurements of blank $(n=60)$ heated in a water bath at $90^{\circ} \mathrm{C}$ for $50 \mathrm{~min}$.

\section{Results and Discussion}

\subsection{Optimization of Heating Temperature and Time for Maximum Generation of Hydrogen Cyanide}

Figure 4A shows the concentration of hydrogen cyanide $(\mathrm{HCN})$ from the headspace of Macadamia flower samples heated at 30, 40,50,60,70, and $100^{\circ} \mathrm{C}$ for $20,30,45,60$, and $80 \mathrm{~min}$. For all heating times, the headspace $\mathrm{HCN}$ concentration increased from 30 to $50^{\circ} \mathrm{C}$ and decreased linearly beyond $50{ }^{\circ} \mathrm{C}$. Thus, $\mathrm{HCN}$ generation in Macadamia was maximum at $50^{\circ} \mathrm{C}$. These results suggest that the optimum temperature for enzymatic activity of endogenous dhurrinase and $\alpha$-hydroxynitrile lyase is $50{ }^{\circ} \mathrm{C}$ (Figure 1). At higher heating temperatures (i.e., above $50^{\circ} \mathrm{C}$ ), cyanide production decreased, which could be caused by decreased enzyme activity or inactivation and, therefore, reduced subsequent hydrolysis reaction of the main cyanogenic glycoside dhurrin (Figure $4 \mathrm{~A}$ ). It is interesting to note that the decreasing production of cyanide at higher temperatures $\left(60-100^{\circ} \mathrm{C}\right)$ is gradual rather than an abrupt cyanide reduction that could be expected from thermally induced enzyme inactivation. The measured cyanide at high temperature could be produced from other thermolabile cyanogenic glycosides that are present in minor amounts. At high temperature, the isomers of dhurrin such as taxiphyllin, zierin, and $p$-glucosyloxy-mandelonitrile can readily dissociate and release cyanide 
without enzymatic hydrolysis [40-42]. Therefore, the cyanide released from the thermally induced decomposition of these minor cyanogenic glycosides could be contributing to the detected cyanide in the headspace of Macadamia flower samples heated at higher temperatures.
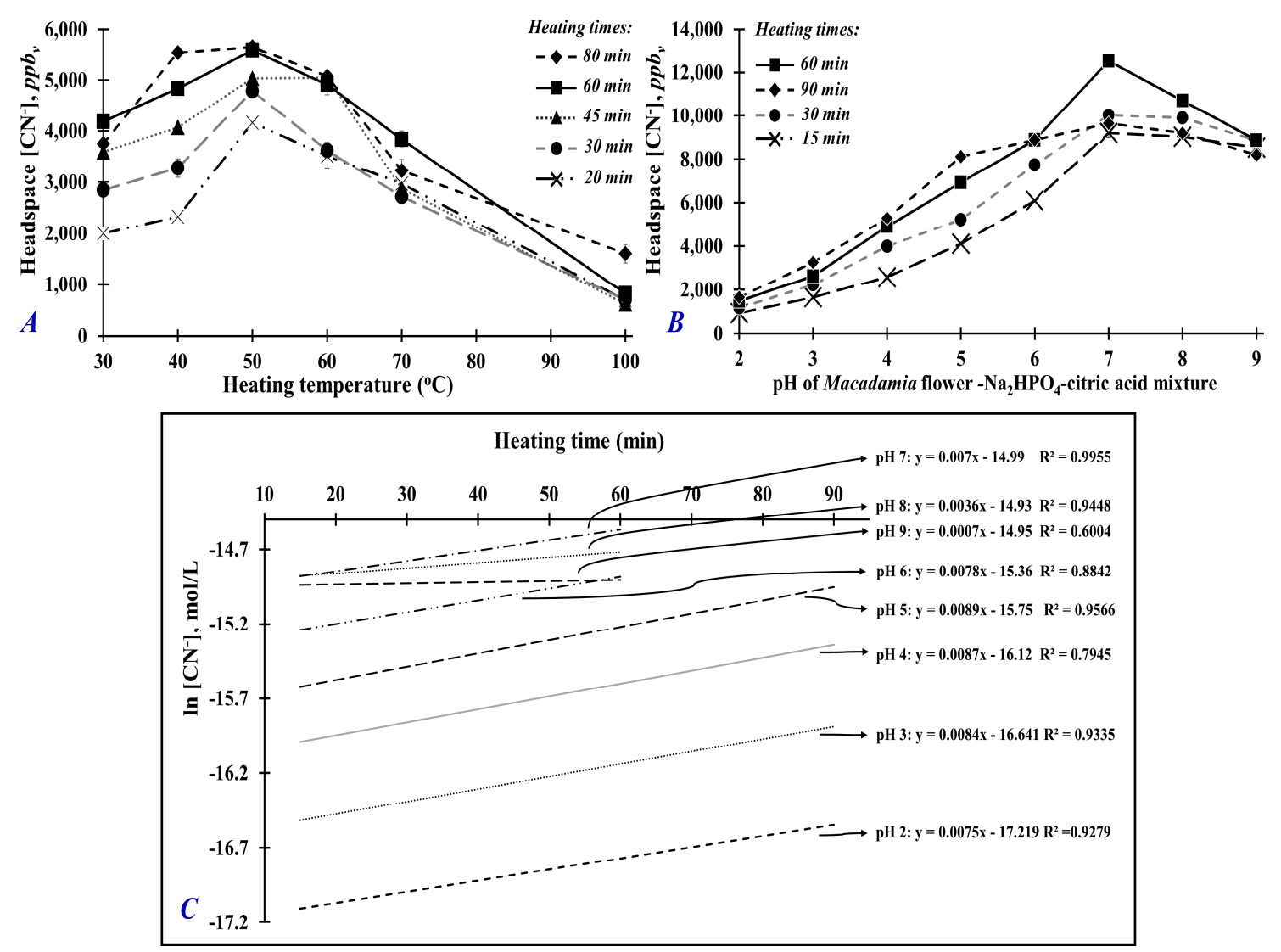

Figure 4. (A) Hydrogen cyanide ( $\mathrm{HCN})$ concentration in the headspace of Macadamia flower heated at various temperatures $\left(30,40,50,60,70\right.$, and $\left.100{ }^{\circ} \mathrm{C}\right)$ and different heating times $(20,30,45,60$, and $80 \mathrm{~min}$ ). (B) Hydrogen cyanide concentration in the headspace of Macadamia flower treated with $\mathrm{Na}_{2} \mathrm{HPO}_{4}$-citric acid mixture buffered at different $\mathrm{pH}(2,3,4,5,6,7,8$, and 9$)$ and heated at $50{ }^{\circ} \mathrm{C}$ for 15, 30, 60, and $90 \mathrm{~min}$ heating times. (C) Hydrolysis reaction rate analysis using [HCN, $\mathrm{mol} / \mathrm{L}]$ concentration analyzed in the headspace of Macadamia flower treated with $\mathrm{Na}_{2} \mathrm{HPO}_{4}$-citric acid mixture buffered at different $\mathrm{pH}(2,3,4,5,6,7,8$, and 9$)$ and heated at $50{ }^{\circ} \mathrm{C}$ for $60 \mathrm{~min}$. Standard error analysis was evaluated at $95 \%$ confidence intervals.

In addition, the longer the heating time, the higher the HCN concentration, with the longest heating times (60 and $80 \mathrm{~min}$ ) generating the highest $\mathrm{HCN}$ concentration (Figure $4 \mathrm{~A}$ ). The maximum $\mathrm{HCN}$ concentration was reached when samples were heated at $40-50{ }^{\circ} \mathrm{C}$ for $80 \mathrm{~min}$ or $50^{\circ} \mathrm{C}$ for $60 \mathrm{~min}$. From these results, the optimum heating time and temperature were determined to be $50^{\circ} \mathrm{C}$ for $60 \mathrm{~min}$, which were used for succeeding experiments.

\subsection{Optimization of Mixture's $p H$ for Maximum Generation of Hydrogen Cyanide}

Figure 4B shows the headspace concentration of hydrogen cyanide above Macadamia flower samples treated with $\mathrm{Na}_{2} \mathrm{HPO}_{4}$-citric acid buffered solutions at different $\mathrm{pH}(2,3,4,5,6,7,8,9)$ and heated at $50{ }^{\circ} \mathrm{C}$ for $15,30,60$, and $90 \mathrm{~min}$. As the $\mathrm{pH}$ increased from $\mathrm{pH} 2$ to 7 , the concentration of $\mathrm{HCN}$ increased. From pH 7 to 9, the concentration of $\mathrm{HCN}$ decreased slightly. The Macadamia flower sample treated with $\mathrm{pH} 7$ buffer and heated at $50{ }^{\circ} \mathrm{C}$ for $60 \mathrm{~min}$ generated the highest headspace concentration of HCN. This result suggests that these conditions are optimum for the underlying 
enzymatic activities involved in the hydrolysis reaction of cyanogenic glycoside compounds producing hydrogen cyanide gas (Figure 1).

When Macadamia flower was heated at $50^{\circ} \mathrm{C}$ for 60 min under its normal physiological $\mathrm{pH}(\mathrm{pH}$ 4.35), the HCN level was only about 4900-5600 $p p b_{v}$ (Figure 4A,B). Increasing the treatment's $\mathrm{pH}$ to $\mathrm{pH}$ 7 , significantly increased the headspace $\mathrm{HCN}$ concentration by $200-250 \%\left(\sim 12,500 p p b_{v}\right)$. At a more basic $\mathrm{pH}$ ( $\mathrm{pH} 8$ or 9), HCN concentration was still significantly higher than the concentration at acidic $\mathrm{pH}$ (pH 6 and below), but it was lower than that at $\mathrm{pH} 7$.

Further analysis of data was done by plotting the hydrogen cyanide concentration as a function of $\mathrm{pH}$ (Figure 4C), the hydrolysis reaction of cyanogenic glycosides at $50{ }^{\circ} \mathrm{C}$ could be described as a first-order reaction with respect to the production of hydrogen cyanide. A constant pseudo first-order rate value $\left(k=0.0081 \pm 0.0007 \mathrm{M} \mathrm{min}^{-1}\right)$ was determined from the linear regression slopes of $\ln [\mathrm{HCN}]$, mol L ${ }^{-1}$ versus heating time ( $\mathrm{min}$ ) plots for $\mathrm{pH} 2,3,4,5,6$, and 7 . At $\mathrm{pH} 8$ and 9, the 90 min data point had to be excluded. The calculated empirical rates of hydrogen cyanide production $(\mathrm{d}[\mathrm{HCN}] / \mathrm{d} t)$ at different $\mathrm{pH}$ (Table 1) suggest that hydrogen cyanide production is slower at acidic $\mathrm{pH}$ values $(\mathrm{pH}$ $2,3,4,5$, and 6), increases at basic $\mathrm{pH}$, but reaches a peak at $\mathrm{pH} 7$. These findings are similar to the results of the study by Johansen and co-workers [17]. According to their study, hydrolysis of the cyanogenic glycoside, dhurrin, follows a first-order reaction with respect to dhurrin and the rate of dhurrin hydrolysis is very slow at low $\mathrm{pH}$ values but strongly increases as the $\mathrm{pH}$ is increased. Thus, the first-order rate of hydrolysis of cyanogenic glycoside dhurrin in aqueous solution is supported by the in vitro hydrolysis of cyanogenic glycosides in Macadamia flower as reported by the present study.

Table 1. Empirical rates of [HCN] production of Macadamia flower treated with $\mathrm{Na}_{2} \mathrm{HPO}_{4}$-citric acid mixture buffered at different $\mathrm{pH}$ and heated at $50{ }^{\circ} \mathrm{C}$ for $60 \mathrm{~min}$.

\begin{tabular}{cc}
\hline $\begin{array}{c}\text { pH of Macadamia Flower- } \mathbf{N a}_{2} \mathbf{H P O}_{4}-\text { Citric } \\
\text { Acid Buffered Mixture }\end{array}$ & $\begin{array}{c}\text { Empirical Rate of }[\mathbf{H C N}] \text { Production at } \mathbf{5 0}{ }^{\circ} \mathbf{C} \\
(\mathbf{d}[\mathbf{H C N}] / \mathbf{d} \boldsymbol{t}), \mathbf{M} \cdot \mathbf{L}^{\mathbf{- 1}} \cdot \mathbf{m i n}^{-\mathbf{1}}\end{array}$ \\
\hline 2 & $4.61 \times 10^{-10} \pm 0.2 \times 10^{-10}$ \\
3 & $8.25 \times 10^{-10} \pm 0.2 \times 10^{-10}$ \\
4 & $1.95 \times 10^{-09} \pm 0.07 \times 10^{-09}$ \\
5 & $2.36 \times 10^{-09} \pm 0.08 \times 10^{-09}$ \\
6 & $2.34 \times 10^{-09} \pm 0.08 \times 10^{-09}$ \\
7 & $2.79 \times 10^{-10} \pm 2 \times 10^{-10}$ \\
8 & $1.40 \times 10^{-09} \pm 0.2 \times 10^{-09}$ \\
9 & $2.78 \times 10^{-10} \pm 4 \times 10^{-10}$ \\
\hline
\end{tabular}

\subsection{Headspace Concentration of Hydrogen Cyanide above Macadamia Flowers, Leaves, Nuts, and Husks}

Figure 5 shows the headspace concentration of hydrogen cyanide measured by SIFT-MS directly above the Macadamia samples treated with $\mathrm{pH} 7$ buffered solution and heated at $50{ }^{\circ} \mathrm{C}$ for $60 \mathrm{~min}$. Based on this figure, Macadamia flowers produced the significantly highest levels of hydrogen cyanide $\left(12,535 \pm 11 p p b_{v}\right)$, followed by the leaves $\left(513 \pm 0.6 p p b_{v}\right)$, husks (21 $\pm 0.1 p p b_{v},(695) ; 256 \pm 0.4$ $p p b_{v},(\mathrm{Oc}) ; 476 \pm 0.7 p p b_{v}$, (A16), and nuts $\left(5.8 \pm 0.1 p p b_{v}\right)$ at $p<0.05$. Interestingly, the hydrogen cyanide concentration in Macadamia flowers was approximately 2-3 times higher than the highest concentration of cyanide detected in M. ternifolia cotyledon ( 4800-6500 $\left.p p b_{v}\right)$ [6,43]. Previous reports have mentioned that cyanogenic compounds are highest in growing tissues of plants and that activation of metabolic processes coincide with cyanogenic glycoside production $[6,44]$. The flower is the main reproductive organ of a plant and has very active and complex morphological and physiological features, which support an abundance of ecological functions related to floral development and plant reproduction [45-47]. For instance, de novo synthesis of amino acids, enzymes, and structural proteins, which are precursors of $\mathrm{N}$-containing secondary metabolites (such as cyanogenic glycosides) and signaling molecules, all occur in floral tissues [47]. These complex metabolic processes during floral development and growth could be contributing to the increased biosynthesis of cyanogenic glycosides 
resulting in the higher concentration of hydrogen cyanide generated in the flower than in the other parts of Macadamia.

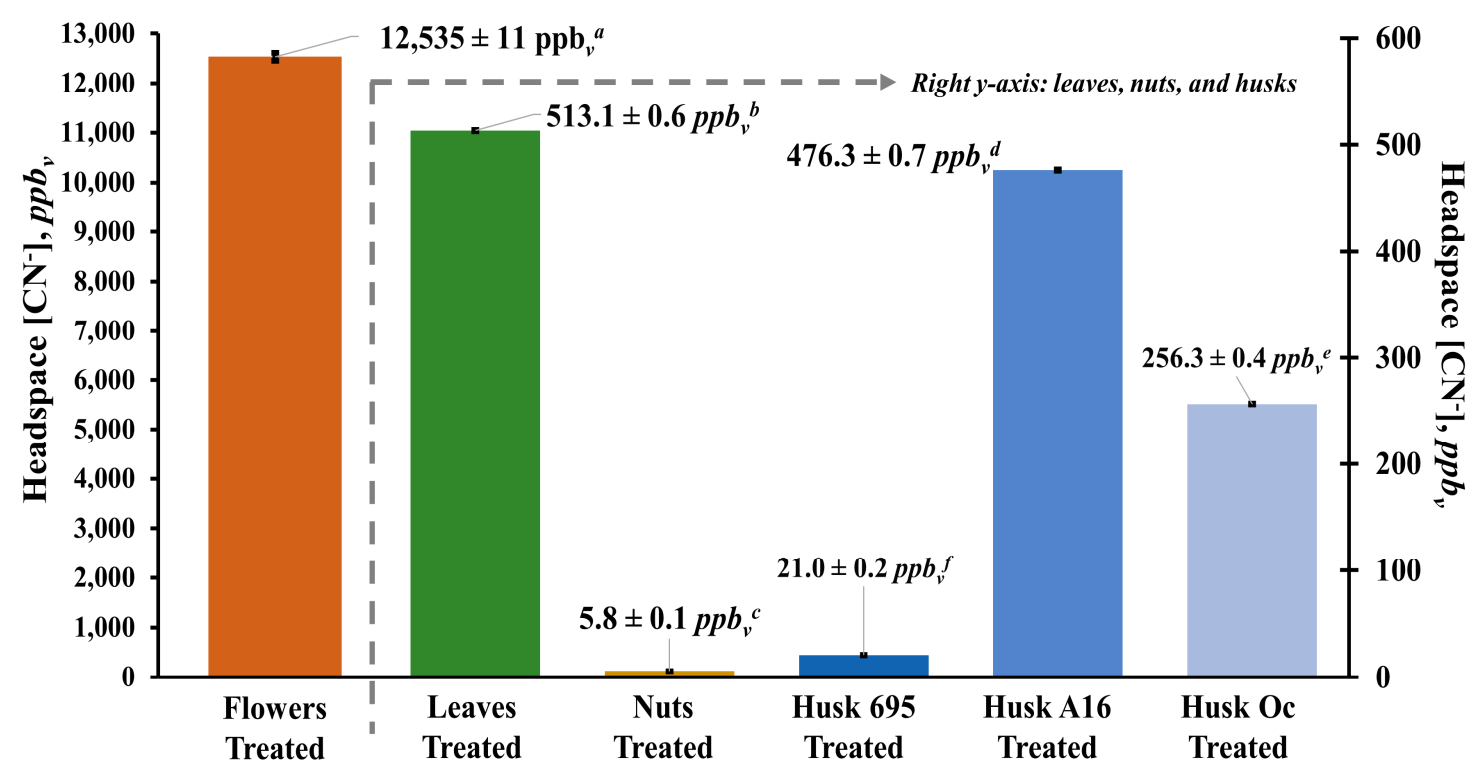

Figure 5. Hydrogen cyanide (HCN) concentration directly analyzed in the headspace of Macadamia flowers, leaves, nuts, and three varieties of Macadamia husks (695, A16, and Oc) treated with $\mathrm{Na}_{2} \mathrm{HPO}_{4}$-citric acid mixture buffered at $\mathrm{pH} 7$ and heated at $50{ }^{\circ} \mathrm{C}$ for $60 \mathrm{~min}$. Different superscript letters $(a, b, c, d, e$, or $f)$ indicate significant differences in mean $\mathrm{HCN}$ concentration at $p<0.05(95 \%$ confidence intervals).

The concentration of hydrogen cyanide in Macadamia leaves $\left(513 \pm 0.6 p p b_{v}\right)$ is within the concentration range of cyanide (364-1403 $p p b_{v}$ ) detected in the leaf tissue of M. ternifolia, M. integrifolia, and M. tetraphylla species during their early to mid-developmental stages (3rd-4th week) [6]. Young leaves were observed to contain higher amounts of cyanogenic glycosides, which could be due to the copious amounts of carbon and nitrogen precursors readily available during germination, so there is rapid biosynthesis of cyanogenic compounds. Cyanogenic glycoside in leaf tissue was, however, observed to decrease with plant maturation because these compounds are rapidly metabolized and broken down as the leaves become older [6,48-50].

Macadamia husks are the fleshy green fibrous pericarp covering the conical or spherical hard brown shell enclosure of Macadamia nuts [51]. Similar to Macadamia flowers, there are no available published data reported for the hydrogen cyanide concentration in Macadamia husks for comparison. Moreover, the hydrogen cyanide concentration of husks analyzed from three different Macadamia varieties were significantly different: $21 \pm 0.1 p p b_{v}$ for variety 695; $256 \pm 0.4 p p b_{v}$ for variety Oc; and $476 \pm 0.7 p p b_{v}$ for variety A16 (Figure 5). It was previously reported that the quantities of cyanogenic glycosides in Macadamia seedlings and other plants vary according to species, developmental stage, and tissue type; however, the cyanogenic glycosides in the varieties of Macadamia husk used in this study have yet to be conclusively identified [6,52].

Seeds of Macadamia species are also capable of accumulating cyanogenic glycoside compounds and the concentration varies depending on the variety $[6,43]$. In the present study, the hydrogen cyanide concentration of Macadamia nuts $\left(5.8 \pm 0.1 p p b_{v}\right)$ was lower than the reported cyanide concentrations in commercially used seeds $\left(\sim 74 p p b_{v}\right)$ of $M$. integrifolia or $M$. tetraphylla and significantly lower than the concentration detected in M. ternifolia $\left(\sim 4800 p p b_{v}\right)$, which is considered to be inedible. 


\subsection{Dhurrin and Total Cyanide Concentrations in Untreated and Treated Macadamia Plant Part Extracts}

Figure 6 shows the concentration of cyanogenic glycoside dhurrin from the different Macadamia plant part extracts with different treatments. Fresh, untreated Macadamia flower $(424.4 \pm 0.6 \mathrm{mg} / \mathrm{L}) \mathrm{had}$ the highest amount of dhurrin compared to the fresh, untreated leaves $(97.1 \pm 0.6 \mathrm{mg} / \mathrm{L})$ (Figure 6A), fresh nuts $(0.43 \pm 0.07 \mathrm{mg} / \mathrm{L})$, or the different husk varieties $(695: 0.63 \pm 0.04 \mathrm{mg} / \mathrm{L} ; \mathrm{A} 16: 11.1 \pm 0.3 \mathrm{mg} / \mathrm{L}$; Oc: $6.1 \pm 0.3 \mathrm{mg} / \mathrm{L})$ (Figure $6 \mathrm{C}$ ).
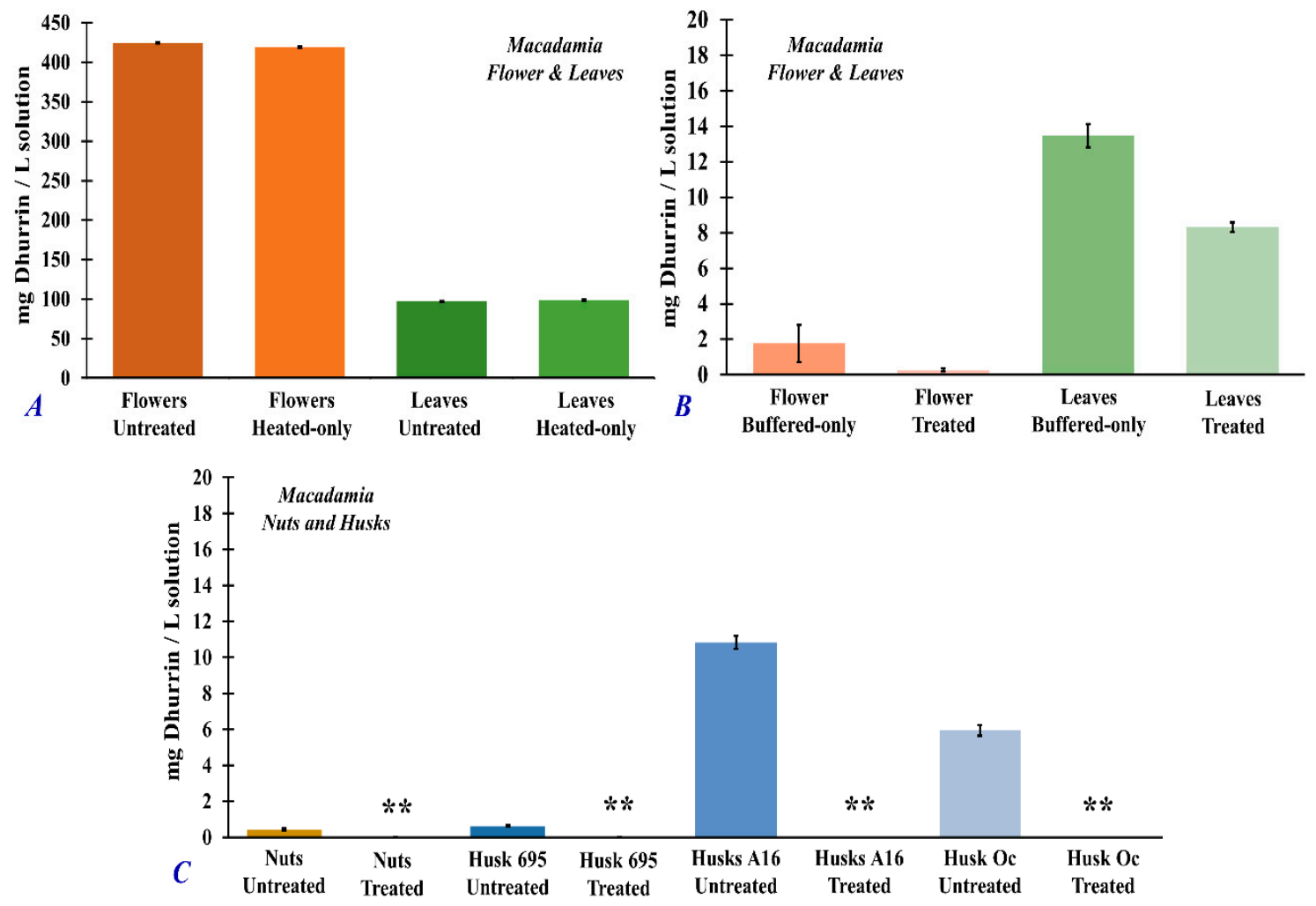

Figure 6. Dhurrin concentration (mg dhurrin/L solution) measured by HPLC-DAD from the different extracts of Macadamia plant parts ((A,B) flowers and leaves; (C) nuts and husks varieties 695, A16, and Oc) in untreated samples (fresh, no treatment), heated-only samples $\left(50{ }^{\circ} \mathrm{C}\right.$ for $60 \mathrm{~min}$ ), buffered-only samples (samples treated with $\mathrm{pH} 7, \mathrm{Na}_{2} \mathrm{HPO}_{4}$-citric acid buffer solution), and treated samples (samples treated with $\mathrm{pH} 7, \mathrm{Na}_{2} \mathrm{HPO}_{4}$-citric acid buffer solution and heated at $50{ }^{\circ} \mathrm{C}$ for $60 \mathrm{~min}$ ). ${ }^{* *}$ Means negligible values. Standard error analysis was evaluated at $95 \%$ confidence intervals.

The cyanide concentration in the extracts have the same trend as the dhurrin concentration. Figure 7 shows the total cyanide concentration of the fresh, untreated Macadamia flower $(417.7 \pm 0.8 \mathrm{mg} / \mathrm{L})$, leaves $(167 \pm 2 \mathrm{mg} / \mathrm{L})$, nuts $(67.1 \pm 0.6 \mathrm{mg} / \mathrm{L})$, and husks (695: $94.3 \pm 0.7 \mathrm{mg} / \mathrm{L} ; \mathrm{A} 16: 23.9 \pm 0.1 \mathrm{mg} / \mathrm{L} ; \mathrm{Oc}$ : $50.6 \pm 0.4 \mathrm{mg} / \mathrm{L}$ ). After full sample treatment using the optimized conditions (i.e., samples treated with $\mathrm{pH} 7$ buffer solution and heated at $50{ }^{\circ} \mathrm{C}$ for $60 \mathrm{~min}$ ), significant amounts of dhurrin and cyanide were removed in the analyzed extracts as shown in Figures 6 and 7, respectively.

It is interesting to note that heating samples at $50^{\circ} \mathrm{C}$ for $60 \mathrm{~min}$ without $\mathrm{pH}$ adjustment (heated-only samples) had little to no effect on the removal of dhurrin (Figure 6A) or cyanide (Figure 7A) in Macadamia flower and leaf samples. On the other hand, treating the Macadamia flower and leaf samples with buffered solution at $\mathrm{pH} 7$ without heating (buffered-only), resulted in significant removal of dhurrin (Figure 6B: flower, $419 \pm 1 \mathrm{mg} / \mathrm{L}$; leaves, $98 \pm 1 \mathrm{mg} / \mathrm{L}$ ) and cyanide (Figure 7A: flower, $370 \pm 2 \mathrm{mg} / \mathrm{L}$; leaves, $48 \pm 1 \mathrm{mg} / \mathrm{L}$ ) in the extracts. Analysis of treatment efficiencies (Table 2) showed that the full treatment of samples (i.e., treated samples) by heating $\left(50{ }^{\circ} \mathrm{C}, 60 \mathrm{~min}\right)$ and $\mathrm{pH} 7$ adjustment results in 93-100\% removal of dhurrin and about $81-91 \%$ removal of cyanide in the different Macadamia plant 
parts. Treatment by heating alone was only about $1 \%$ effective in the removal of dhurrin and only about $5-12 \%$ effective in the removal of cyanide (Table 2). However, treating the Macadamia flower and leaf samples with buffered solution at $\mathrm{pH} 7$ without heating (buffered-only), treatment produced about similar removal effectivity (Table 2) of dhurrin (93-100\%) and cyanide (89-91\%) as that of the fully treated samples heated at $50^{\circ} \mathrm{C}$ for $60 \mathrm{~min}$ at $\mathrm{pH} 7$.
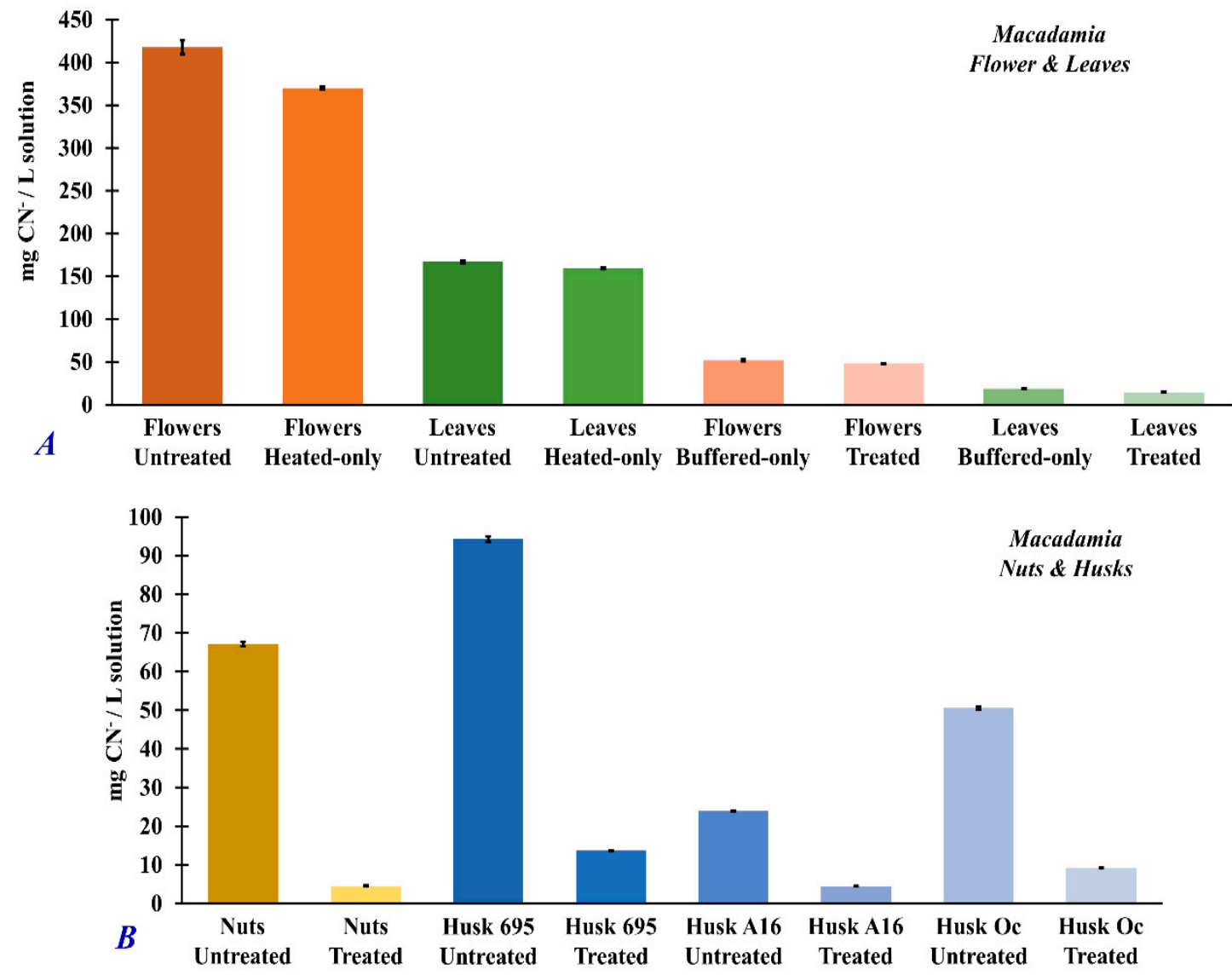

Figure 7. Total cyanide concentration ( $\mathrm{mg} \mathrm{CN}^{-} / \mathrm{L}$ solution) measured by $\mathrm{UV}$-vis spectrophotometer from the different extracts of Macadamia plant parts ((A) flowers and leaves; (B) nuts and husk varieties 695, A16, and Oc) in untreated samples (fresh, no treatment), heated-only samples (samples heated at $50{ }^{\circ} \mathrm{C}$ for $60 \mathrm{~min}$ ), buffered-only samples (samples treated with $\mathrm{pH} 7, \mathrm{Na}_{2} \mathrm{HPO}_{4}$-citric acid buffer solution), and treated samples (samples treated with $\mathrm{pH} 7, \mathrm{Na}_{2} \mathrm{HPO}_{4}$-citric acid buffer solution, and heated at $50{ }^{\circ} \mathrm{C}$ for $60 \mathrm{~min}$ ). Standard error analysis was evaluated at $95 \%$ confidence intervals.

Table 2. Dhurrin and total cyanide (mg/g sample) in untreated and treated Macadamia flowers, leaves, nuts, and husk varieties and treatment removal efficiency (\%).

\begin{tabular}{lcccc}
\hline Samples & $\begin{array}{c}\text { mg Dhurrin/g } \\
\text { Sample }\end{array}$ & $\begin{array}{c}\text { \% Treatment } \\
\text { Efficiency }\end{array}$ & $\begin{array}{c}\text { Total Cyanide (mg/g } \\
\text { sample) }\end{array}$ & $\begin{array}{c}\text { \% Treatment } \\
\text { Efficiency }\end{array}$ \\
\hline Macadamia Flower Untreated & $37.14( \pm 0.05)$ & - & $4.18\left( \pm 8.0 \times 10^{-2}\right)$ & - \\
$\quad$ Flowers (heated only) & $36.68( \pm 0.09)$ & $1.2( \pm 0.5)$ & $3.70\left( \pm 7.5 \times 10^{-3}\right)$ & $11.5( \pm 0.2)$ \\
$\quad$ Flowers (buffered only) & $0.15( \pm 0.09)$ & $99.6( \pm 0.5)$ & $0.52\left( \pm 1.1 \times 10^{-2}\right)$ & $87.6( \pm 2.9)$ \\
Flowers Treated & $0.02( \pm 0.09)$ & $99.9( \pm 0.5)$ & $0.48\left( \pm 3.6 \times 10^{-4}\right)$ & $88.5( \pm 2.9)$ \\
Macadamia Leaves Untreated & $8.50( \pm 0.05)$ & - & $1.67\left( \pm 1.8 \times 10^{-2}\right)$ & - \\
$\quad$ Leaves (heated only) & $8.60( \pm 0.09)$ & $1.2( \pm 0.5)$ & $1.59\left( \pm 7.5 \times 10^{-3}\right)$ & $4.6( \pm 0.2)$ \\
$\quad$ Leaves (buffered only) & $1.18( \pm 0.06)$ & $86.1( \pm 0.3)$ & $0.19\left( \pm 3.3 \times 10^{-3}\right)$ & $88.7( \pm 1.6)$ \\
$\quad$ Leaves Treated & $0.73( \pm 0.09)$ & $93.1( \pm 0.5)$ & $0.15\left( \pm 1.6 \times 10^{-3}\right)$ & $91.3( \pm 1.6)$ \\
Macadamia Nuts Untreated & $0.04( \pm 0.07)$ & - & $0.67\left( \pm 6.3 \times 10^{-3}\right)$ & - \\
$\quad$ Nuts Treated & $0.00( \pm 0.09)$ & $100.0( \pm 0.5)$ & $0.05\left( \pm 2.2 \times 10^{-3}\right)$ & $93.2( \pm 1.4)$ \\
Macadamia Husks 695 & $0.05( \pm 0.07)$ & - & $0.94\left( \pm 7.4 \times 10^{-3}\right)$ & - \\
Untreated & & & & \\
\hline
\end{tabular}


Table 2. Cont.

\begin{tabular}{lcccc}
\hline Samples & $\begin{array}{c}\text { mg Dhurrin/g } \\
\text { Sample }\end{array}$ & $\begin{array}{c}\text { \% Treatment } \\
\text { Efficiency }\end{array}$ & $\begin{array}{c}\text { Total Cyanide }(\mathrm{mg} / \mathrm{g} \\
\text { sample })\end{array}$ & $\begin{array}{c}\text { \% Treatment } \\
\text { Efficiency }\end{array}$ \\
\hline Husks 695 Treated & $0.00( \pm 0.09)$ & $100.0( \pm 0.5)$ & $0.14\left( \pm 2.9 \times 10^{-4}\right)$ & $85.5( \pm 1.2)$ \\
$\begin{array}{l}\text { Macadamia Husks A16 } \\
\text { Untreated }\end{array}$ & $0.97( \pm 0.07)$ & - & $0.24\left( \pm 1.2 \times 10^{-3}\right)$ & - \\
$\quad \begin{array}{l}\text { Husks A16 Treated } \\
\text { Macadamia Husks Oc }\end{array}$ & $0.00( \pm 0.09)$ & $100.0( \pm 0.5)$ & $0.04\left( \pm 3.6 \times 10^{-4}\right)$ & $81.3( \pm 0.9)$ \\
$\begin{array}{c}\text { Untreated } \\
\text { Husks Oc Treated }\end{array}$ & $0.53( \pm 0.07)$ & - & $0.51\left( \pm 4.1 \times 10^{-3}\right)$ & - \\
\hline
\end{tabular}

* Standard error analysis was evaluated at $95 \%$ confidence intervals.

\section{Conclusions}

The optimum conditions for the maximum release of hydrogen cyanide in Macadamia samples were $50^{\circ} \mathrm{C}, 60 \mathrm{~min}$ at $\mathrm{pH}$ 7. Under these treatment conditions, trace amounts of hydrogen cyanide could still be detected in the headspace directly above the different Macadamia plant part samples using SIFT-MS. The measured hydrogen cyanide in the headspace of the treated samples were 12,535 $\pm 11 p p b_{v}$ (flower), $513 \pm 0.6 p p b_{v}$ (leaves), $6 \pm 0.1 p p b_{v}$ (nuts), $476 \pm 0.7 p p b_{v}$ (husk A16), $256 \pm 0.4 p p b_{v}$ (husk Oc), and $21 \pm 0.1$ $p p b_{v}$ (husk 695). Treatment of Macadamia samples under these optimum conditions produced $93-100 \%$ removal of dhurrin and $81-91 \%$ removal of total cyanide in the sample extracts. Treatment by $\mathrm{pH} 7$ adjustment (buffered-only) without heating also resulted in an effective removal of dhurrin (86-100\%) and total cyanide (88-89\%) in Macadamia extract similar to the full, optimized treatment conditions. Heating the samples alone at $50{ }^{\circ} \mathrm{C}$ for $60 \mathrm{~min}$ without $\mathrm{pH}$ adjustment was not effective in the hydrolysis and removal of cyanogenic glycoside dhurrin and total cyanide in Macadamia samples. The varying concentration of generated hydrogen cyanide could be correspondingly attributed to the concentration of cyanogenic glycosides (such as dhurrin) from the different parts of the Macadamia plant and their subsequent hydrolysis to hydrogen cyanide. Cyanogenic glycosides were greatest in Macadamia flowers, followed by the leaves and husks (depending on variety), and lowest in nuts. The results indicate that the hydrolysis of cyanogenic glycosides in Macadamia is predominantly induced by $\mathrm{pH}$ changes rather than by heat. This further suggests that the enzymatic hydrolysis involved in cyanogenesis is chiefly $\mathrm{pH}$-directed rather than thermally induced. In addition, the hydrolysis reaction of cyanogenic glycosides could be described as a first-order reaction with respect to the in vitro production of hydrogen cyanide.

These results provide further insights into the cyanogenic systems in Macadamia. Moreover, the evaluated optimum conditions for the hydrolysis of dhurrin and removal and release of hydrogen cyanide could be helpful for the effective processing of different parts of Macadamia. Such information provides some guidelines toward the safe production, utilization, and consumption of Macadamia-based products.

Author Contributions: H.Z.C., S.A.B., and X.H. conceptualized the research. H.Z.C. and J.L. performed the experiments and wrote the manuscript. H.Z.C. supervised the research. H.Z.C., S.A.B., and X.H. reviewed and edited the manuscript. All authors have read and agreed to the published version of the manuscript.

Funding: This research received no external funding.

Acknowledgments: The authors would like to acknowledge the support from the Guangdong Provincial Department of Science and Technology R\&D program (2018B020239001) and the Special Fund for Agro-Scientific Research in the Public Interest (201303077).

Conflicts of Interest: The authors declare no conflict of interest. 


\section{References}

1. Quinn, L.A.; Tang, H.H. Antioxidant properties of phenolic compounds in Macadamia nuts. J. Am. Oil Chem. Soc. 1996, 73, 1585-1588. [CrossRef]

2. Lim, T.K. Macadamia integrifolia. In Edible Medicinal and Non-Medicinal Plants; Lim, T.K., Ed.; Springer: Dordrecht, The Netherlands, 2013; Volume 5, pp. 494-501.

3. Dailey, A.; Vuong, Q.V. Effect of extraction solvents on recovery of bioactive compound and antioxidant properties from Macadamia (Macadamia tetraphylla) skin waste. Cogent Food Agric. 2015, 1, 1115646. [CrossRef]

4. Wood, L.G.; Garg, M.L. Macadamia nuts (M. Integrifolia and M. Tetraphylla) and their use in hypercholesterolemic subjects. In Nuts and Seeds in Health and Disease Prevention; Preedy, V.R., Watson, R.R., Patel, V.B., Eds.; Elsevier: London, UK, 2011; pp. 717-725.

5. Aquino-Bolaños, E.N.; Mapel-Velazco, L.; Martin-del-Campo, S.T.; Chavez-Servia, J.L.; Martinez, A.J.; Verdalet-Guzman, I. Fatty acids profile of oil from nine varieties of Macadamia nut. Int. J. Food Prop. 2017, 20, 1262-1269. [CrossRef]

6. Dahler, J.M.; McConchie, C.A.; Turnbull, C.G.N. Quantification of cyanogenic glycosides in seedlings of three Macadamia (Proteaceae) species. Aust. J. Bot. 1995, 43, 619-628. [CrossRef]

7. Bolarinwa, I.F.; Orfila, C.; Morgan, R.A. Amygdalin content of seeds, kernels, and food products commercially available in the UK. Food Chem. 2014, 152, 133-139. [CrossRef]

8. Poulton, J.E. Cyanogenesis in plants. Plant Physiol. 1990, 94, 401-405. [CrossRef]

9. Møller, B.L. Functional diversifications of cyanogenic glucosides. Curr. Opin. Plant Biol. 2010, 13, 337-346. [CrossRef]

10. Seigler, D.S. Cyanide and cyanogenic glycosides. In Herbivores: Their Interactions with Secondary Plant Metabolites; Rosenthal, G.A., Berenbaum, M.R., Eds.; Academic Press: San Diego, CA, USA, 1991; pp. $35-77$.

11. Miller, R.E.; Jensen, R.; Woodrow, I.E. Frequency of cyanogenesis in tropical rainforests of Far North Queensland, Australia. Ann. Bot. 2006, 97, 1017-1044. [CrossRef]

12. Thayer, S.S.; Conn, E.E. Subcellular localization of dhurrin $\beta$-glucosidase and hydroxynitrile lyase in the mesophyll cells of Sorghum leaf blades. Plant Physiol. 1981, 67, 617-622. [CrossRef]

13. Hickel, A.; Hasslacher, M.; Griengl, H. Hydroxynitrile lyases: Functions and properties. Physiol. Plant. 1996, 98, 891-898. [CrossRef]

14. Halkier, B.A.; Møller, B.L. Biosynthesis of the cyanogenic glucoside dhurrin in seedlings of Sorghum bicolor (L.) Moench and partial purification of the enzyme system involved. Plant Physiol. 1989, 90, 1552-1559. [CrossRef] [PubMed]

15. Conn, E.E. The metabolism of a natural product: Lessons learned from cyanogenic glycosides. Planta Med. 1991, 57, S1-S9. [CrossRef] [PubMed]

16. Nahrstedt, A. Cyanogenesis and Foodplants. In Phytochemistry and Agriculture; van Beek, T.A., Breteler, H., Eds.; Clarendon Press: Oxford, UK, 1993; pp. 107-129.

17. Johansen, H.; Rasmussen, L.H.; Olsen, C.E.; Hansen, H.C.B. Rate of hydrolysis and degradation of the cyanogenic glycoside-Dhurrin-In soil. Chemosphere 2007, 67, 259-266. [CrossRef]

18. Mao, C.-H.; Anderson, L. Partial purification and characterization of two $\beta$-glucosidases from Sorghum tissues. Phytochemistry 1967, 6, 473-483. [CrossRef]

19. Egekeze, J.O.; Oehme, F.W. Cyanides and their toxicity. A literature review. Vet. Quart. 1980, 2, $104-114$. [CrossRef] [PubMed]

20. Onojah, P.K.; Odin, E.M. Cyanogenic glycoside in food plants. Int. J. Innov. Sci. Math. 2015, 3, $2347-9051$.

21. Geller, R.J.; Barthold, C.; Saiers, J.A.; Hall, A.H. Pediatric cyanide poisoning: Causes, manifestations, management, and unmet needs. Rev. Pediatr. 2006, 118, 2146-2158. [CrossRef]

22. Miller, R.E.; Tuck, K.L. The rare cyanogenic proteacin, and dhurrin, from foliage of Polyscias australiana, Araliaceae. Phytochemistry 2013, 93, 210-215. [CrossRef]

23. Kriedemann, P.E. Cyanogenesis in Sorghum almum in relation to nitrogen and phosphorus nutrition. Aust. J. Exp. Agric. Anim. Husb. 1964, 4, 15-16. [CrossRef]

24. Jones, D.A. Cyanogenic glycosides and their function. In Phytochemical Ecology; Harbone, J.B., Ed.; Academic Press: London, UK, 1972; pp. 103-124.

25. Bradbury, J.H.; Egan, S.V.; Lynch, M.J. Analysis of cyanide in cassava using acid hydrolysis of cyanogenic glucosides. J. Sci. Food Agric. 1991, 55, 277-290. [CrossRef] 
26. Gleadow, R.M.; Woodrow, I.E. Temporal and spatial variation in cyanogenic glycosides in Eucalyptus cladoclyx. Tree Physiol. 2000, 20, 591-598. [CrossRef] [PubMed]

27. Ma, J.; Dasgupta, P.K. Recent developments in cyanide detection: A review. Anal. Chim. Acta 2010, 673, 117-125. [CrossRef] [PubMed]

28. Nielsen, L.J.; Stuart, P.; Picmanova, M.; Rasmussen, S.; Olsen, C.E.; Harholt, J.; Møller, B.L.; Bjarnholt, N. Dhurrin metabolism in the developing grain of Sorghum bicolor (L.) Moench investigated by metabolite profiling and novel clustering analyses of time-resolved transcriptomic data. BMC Genom. 2016, 17, 1-24. [CrossRef] [PubMed]

29. Castada, H.Z.; Barringer, S.B.; Wick, M. Gas-phase chemical ionization of 4-akyl branched-chain carboxylic acids and 3-methylindole using $\mathrm{H}_{3} \mathrm{O}^{+}, \mathrm{NO}^{+}$, and $\mathrm{O}_{2}{ }^{+}$ions. Rapid Commun. Mass Spectrom. 2017, 31, 1641-1650. [CrossRef]

30. Castada, H.Z.; Polentz, V.; Barringer, S.B.; Wick, M. Temperature-dependent Henry's law constants of 4-alkyl-branched chain fatty acids and 3-methylindole in an oil-air matrix and analysis of volatile in lamb fat using selected ion flow tube mass spectrometry (SIFT-MS). Rapid Commun. Mass Spectrom. 2017, 31, 2135-2145. [CrossRef]

31. Castada, H.Z.; Barringer, S.B. Online, real-time, and direct use of SIFT-MS to measure garlic breath deodorization: A Review. Flavour Fragr. J. 2019, 34, 299-306. [CrossRef]

32. Castada, H.Z.; Hanas, K.; Barringer, S.B. Swiss cheese flavor variability based on correlations of volatile flavor compounds, descriptive sensory attributes, and consumer preference. (Special Issue-Cheese: Technology, Compositional, Physical and Biofunctional Properties). Foods 2019, 8, 78. [CrossRef]

33. Castada, H.Z.; Sun, Z.; Barringer, S.B.; Huang, X. Thermal degradation of $p$-Hydroxybenzoic acid in macadamia nut oil, olive oil, and corn oil. J. Am. Oil Chem. Soc. 2020, in press. [CrossRef]

34. Yu, J.; Castada, H.Z.; Huang, X.; Barringer, S.B. Comparison of encapsulation of garlic oil with $\alpha-, \beta-$ and $\gamma$-cyclodextrin using Selected Ion Flow Tube-Mass Spectrometry (SIFT-MS). J. Food Process. Preserv. 2019, 43, e13865. [CrossRef]

35. De Nicola, G.R.; Leoni, O.; Malaguti, L.; Bernardi, R.; Lazzeri, L. A simple analytical method for dhurrin content evaluation in cyanogenic plants for their utilization in fodder and biofumigation. J. Agric. Food Chem. 2011, 59, 8065-8069. [CrossRef]

36. Sarkiyayi, S.; Agar, T.M. Comparative analysis on the nutritional and anti-nutritional contents of the sweet and bitter cassava varieties. Adv. J. Food Sci. Technol. 2010, 2, 328-334.

37. Omar, N.F.; Hassan, S.A.; Yusoff, U.K.; Abdullah, N.A.P.; Wahab, P.E.M.; Sinniah, U.R. Phenolics, flavonoids, antioxidant activity and cyanogenic glycosides of organic and mineral-base fertilized cassava tubers. Molecules 2012, 17, 2378-2387. [CrossRef] [PubMed]

38. Browne, R.W.; Whitcomb, B.W. Procedures for determination of detection limits: Application to high-performance liquid chromatography analysis of fat-soluble vitamins in human serum. Epidemiology 2010, 21, S4-S9. [CrossRef] [PubMed]

39. Shrivastava, A.; Gupta, V.B. Methods for the determination of limit of detection and limit of quantification of the analytical methods. Chron. Young Sci. 2011, 2, 21-25. [CrossRef]

40. Conn, E.E. Cyanogenic glycosides. J. Agric. Food Chem. 1969, 17, 519-526. [CrossRef]

41. Conn, E.E. Cyanogenic compounds. Ann. Rev. Plant Physiol. 1980, 31, 433-451. [CrossRef]

42. Davis, R.H. Cyanogens. In Toxic Substances in Crop Plants; D'Mello, J.P.F., Duffus, C.M., Duffus, J.H., Eds.; The Royal Society of Chemistry: Cambridge, UK, 1991; pp. 202-225.

43. Ballhorn, D.J. Cyanogenic glycosides in nuts and seeds. In Nuts E Seeds in Health and Disease Prevention; Preedy, V.R., Watson, R.R., Petel, V.B., Eds.; Elsevier Inc.: Oxford, UK, 2011; pp. 129-136.

44. Newton, R.J.; Baltuskonis, D.A.; Goeschl, J.D.; Meckenstock, D.H.; Miller, F.R. Distribution and transformation of soluble carbohydrates during germination growth of sorghum. Crop Sci. 1980, 20, 265-268. [CrossRef]

45. Lang, A.; Nitsch, J.P. Flower and fruit formation. In Differentiation and Development/Differenzierung und Entwicklung. Encyclopedia of Plant Physiology/Handbuch der Pflanzenphysiologie; Allsopp, A., Bloch, R., Bonner, J.T., Bopp, M., Brachet, J., Brown, R., Bunning, E., Buvat, R., Cantino, E.C., Champagnat, P., et al., Eds.; Springer: Berlin, Germany, 1965; pp. 1380-1647.

46. Domingos, S.; Fino, J.; Paulo, O.S.; Oliveira, C.M.; Goulao, L.F. Molecular candidates for early-stage flower-to-fruit transition in stenospermocarpic table grape (Vitis vinifera L.) inflorescences ascribed by differential transcriptome and metabolome profiles. Plant Sci. 2016, 24, 40-56. [CrossRef] 
47. Borghi, M.; Fernie, A.R. Floral metabolism of sugars and amino acids: Implications for pollinators' preferences and seed and fruit set. Plant Physiol. 2017, 175, 1510-1524. [CrossRef]

48. Stafford, H.A. Changes in phenolic compounds \& related enzymes in young plants of sorghum. Phytochemistry 1969, 8, 743-752.

49. Bough, W.A.; Gander, J.E. Exogenous L-tyrosine metabolism and dhurrin turnover in sorghum seedlings. Phytochemistry 1971, 10, 67-77. [CrossRef]

50. Dement, W.A.; Mooney, H.A. Seasonal variation in the production of tannins and cyanogenic glucosides in the chaparral shrub, Heteromeles arbutifolia. Oecologia 1974, 15, 65-76. [CrossRef] [PubMed]

51. Akinsanmi, O.A.; Drenth, A. Characterisation of husk rot in Macadamia. Ann. Appl. Biol. 2017, 170, 104-115. [CrossRef]

52. Lamont, B.B. Injury-induced cyanogenesis in vegetative and reproductive parts of two Grevillea species and their F1 hybrid. Ann. Bot. 1993, 71, 537-542. [CrossRef]

(C) 2020 by the authors. Licensee MDPI, Basel, Switzerland. This article is an open access article distributed under the terms and conditions of the Creative Commons Attribution (CC BY) license (http://creativecommons.org/licenses/by/4.0/). 